\title{
The Effect of International Business on SMEs Growth in Nigeria
}

\author{
- Oladimeji Moruff Sanjo, Mubammed Olaniyi Ibrabim
}

\begin{abstract}
The research examined the effect of international business on SMEs growth in a competitive environment, particularly Nigeria. The secondary data were gathered from the Nigerian Bureau of Statistics and the Central Bank of Nigeria $(\mathrm{CBN})$ annual report. This study adopted ordinary least square method of data analyses. The finding revealed that trade openness as a measure of competitiveness and FDI has no significant effect on SMEs growth in Nigeria. It was also revealed that the exchange rate has a significant effect on SMEs growth in Nigeria, and the level at which exchange rate affects SMEs growth is relatively high. It was further showed that the exchange rate has a negative coefficient indicating that, as the exchange rate reduces SMEs growth increases. It is concluded that trade competitiveness had no significant effect on SMEs growth in Nigeria. It is therefore recommended that government should formulate policies, which will encourage the reduction of exchange rate in the country in order to enhance competition and improve business activities across the country, and improve the growth of SMEs across the country, as well as encouraging entrepreneurship spirit in the country.
\end{abstract}

Keywords: International business, SMEs growth, FDI, Trade openness, Exchange rate JEL Classification: F20

\section{INTRODUCTION}

In the world today, it becomes difficult for countries to survive without a form of exchange or another which involves money, ideas, product and technology. As a result, every economy is affected either positively or negatively. Trade can be drawn from the need to exchange, which developed from the barter arrangement to the currency method. Trade in Nigeria, nevertheless, became general with the introduction of the imposing regulation, which brought in their merchandises and made Nigerians their middle men. The implication of this is that Nigerians came to comprehend the necessity for trade both domestically and internationally.

International business has remained an area of concern to policy makers. Its significance lies on the capacity to acquire goods which cannot be manufactured in a country or which can only be manufactured at a higher cost. Similarly, it allows a nation to trade its locally produced goods to other countries of the world. The performance of a given economy in terms of growth rates of output and per capita income has not only been based on the domestic production and consumption activities but also on international transaction of goods and services (Jhingan 2006).

Small and Medium-scale Enterprises (SMEs) play very important roles in the process of industrialization and sustainable economic growth (Aremu \&Adeyemi, 2011; Terungwa, 2012). Since the 1960s to date, SMEs are being given due recognitions especially in the developed nations for playing very important roles towards fostering accelerated economic growth, development 
and stability within several economies (Gunu, 2004; Onugu, 2005; Aremu, 2010). They make up the largest proportion of business all over the world and play tremendous roles in employment generation, provisions of goods and services, creating a better standard of living as well as immensely contributing to the Gross Domestic Products (GDP) of many countries (Paul, 2010; Ojeka \& Mukoro, 2011).

In Nigeria, SMEs account for fifty percent to employment on average and also fifty percent of its industrial output. SMEs represent about ninety percent of the industrial sector in terms of number of enterprises or firms, and, however, they contribute a meager one percent of GDP (Ariyo, 2004). Industrial and economic developments are flourished by SMEs in the country through efficient utilization of local resources; production of intermediate goods and services; transformation of rural technology. SMEs are the backbone, and they play a significant role in the business landscape of any country, but there are also faced with a lot of obstacles that make the sector not to contribute optimally to the economy. In this regard, Aregbeyen (1999) argues that the industrial development of Nigeria depends, to a large extent, on the growth and development of SME potentials.

Numerous studies have been carried out by past researchers on international trade and international business; however, the researches were conducted in the context of economic development of the nation. With little research on the nexus between international business and SMEs growth by past researchers, this study thus looks to fill the research gap by examining how international business affects the growth of SMEs, especially in the Nigerian environment.

Thus, the objective of this study is to examine the effect of international business on SMEs growth in Nigeria. This will be achieved by giving answers to questions such as: What is the overall effect of international business on SMEs growth in Nigeria?; Does trade openness affect SMEs growth in Nigeria?; What influence does Foreign Direct Investment (FDI) have on SMEs growth in Nigeria?; and How do exchange rates affect SMEs growth in Nigeria?. The answer to these questions is followed by a review of literature in section two, the research methodology in section three, which is followed by data analysis and discussion of findings as well as the summary, conclusion and recommendation.

\section{LITERATURE REVIEW}

\subsection{Concept of International Business}

International business can been defined as business activities across the frontiers that is with the rest of the world. It has been argued that it plays a prominent role in promoting economic growth and productivity in particular, and the debates have been ongoing since several decades ago. Historical validation has revealed that internationally active countries tend to be more productive than countries which produce for the domestic market (Gianni De, Honohan \& Ize, 2003).

The benefit of international business for economic growth and development are difficult to estimate. International business deals with the economic and financial interdependences among nations; international business is a part of our daily life, and international business plays a vital role in shaping economic and social performance and prospects of countries around the world, 
especially those of developing countries(Gianni De, Honohan \& Ize, 2003). There are several risks in international business, which affects its development, and they include economic risk, Political risk, Country buyer and seller risk, Commercial risk. Other international business risks include culture difference, lack of knowledge, overseas markets, language barriers corruption in business and natural risks, these are risks which create the problems for the foreigner investors.

\subsection{Concept of SMEs}

Small and Medium-Scale Enterprises are generally privately owned organizations set-up for the purposes of producing goods or services for profit. The criteria for classifying business enterprises under SMEs differ from country to country (Aremu \& Adeyemi, 2011). The identifiable and predominant criteria across the globe include: size of capital invested, number of staff or employees, size of turnover or sales volumes and value of assets (Ezeh, 1999).

The reliance on the criteria identified above for the categorization of business enterprises under SMEs still varies across the globe (Ezeh, 1999). There is no compromise as to the exact number of employees, size of capital employed, sales volumes or value of assets that qualify a business enterprise to be SME. Relying on the number of employees/staff criterion, for instance, some countries describe all enterprises that have less than 100 employees as SMEs, others are in favor of 50 employees and some expand the net to include all firms who have less than 200 employees (ABS, 2001 Ojeka \& Mukaro, 2011).

The Federal Government of Nigeria in 1990 defined small-scale enterprises for the purpose of a commercial loan as those enterprises with capital investment not exceeding N2 million (excluding cost of land) or a minimum of N5 million (Aremu \& Adeyemi, 2011). Small and Medium Industries Equity Investment Scheme (SMIEIS) defined SMEs as those "enterprises with a total capital employed not less than N1.5 million, but not exceeding N200 million, including working capital, but excluding cost of land and / or with a staff strength of not less than 10 and not more than 300 (Obamuyi, 2007).

SMIEIS (2006) claimed that SMEs are those enterprises that has a total capital employed not below one million five hundred thousand but not exceeding two hundred million including working capital but excluding cost of land, with an employee strength of not below ten and not above three hundred. SMEDAN (2005) defines SMEs based on the following criteria: small- scale enterprises are businesses with ten to forty-nine people with an annual turnover of five to fortynine million Naira while a medium- scale enterprises that have fifty to one hundred and ninetynine employees with a year turnover of fifty to four hundred and ninety-nine million Naira.

In Nigeria, SMEs cover economic activities within all sectors. It is clear from various definitions, showing that there is no single concept that constitutes SMEs; the definitions vary across industries and the globe. SMEs are a heterogeneous group, and SMEs owners may or may not be poor. Some are dynamic, growth-oriented, and innovative while others are not; they preferred to remain small and also to continue as usual. In some countries, SMEs' owners and workers are (or are perceived to be) dominated by a member of particular ethnic groups. 


\subsection{International Business and SMEs Growth}

The impact of international business on SMEs development has generated little volume of empirical studies overtime, with mixed findings using cross sectional, time- series and panel data on the data gathered. Rodriquez \&Rodrick (2000) argued that business policy does affect the volume of business, but there is no strong reason to expect the effect of development to be quantitatively similar to the consequences of change in trade volumes that arise because of reductions in transport, which cause an increase in the world demand. Business restrictions should represent policy responses to real or perceived market imperfections or are used as mechanism for rent extraction. They believed that business policy works differently from natural or geographical barriers to business and other exogenous determinants.

In other stimulating study, Weisbrot \& Baker (2002) argued that business may not be the only key to rapid SMEs growth and development. They noted that the success of some countries that experienced accelerated development did not follow simple path to trade liberalization. However, there are many arguments in the regards to business and growth; one suggests that international business improves resources allocation in the short run or raises the growth rate permanently. There are other arguments that suggest the contrary.

Shafaeddin (2005) posits that business is necessary when an industry reaches a certain level of maturity provided it is undertaken gradually and selectively. In addition, the policy is often implemented along with the devaluation of currency in order to make the exports of the devaluation country's export cheaper and is of good quality, it tends to sell more internationally there by encouraging growth and development (Agbeyegbe, 2006; Obadan, 2006). The ultimate aim is to remove taxes on exports, which will encourage further exportation of goods, and services that will further encourage growth and development, restriction on imports and reduction of imports tariffs.

Thirlwall (1997) in his work explained the possibility that export growth may set up a vicious cycle of growth such that once a country is on the path of growth; it maintains its competitive position in the world trade and performs continually better when compared to other countries.

There has been a growing theoretical evidence of positive relationships between business and development in many developed nations, such relationships have not been proven empirically in developing nations, particularly among African countries. In their attempts to establish such relationships, Edwards (1993) provides a comprehensive review of the key issues on the link between trade and growth in developing countries, particularly the continuing difficulties in obtaining reliable measures of trade policy and identifying precisely the channels through which the outward orientation facilitates growth.

Chen (2013) argued that international business can promote SMEs growth through technology spill over and external stimulation. Similarly, Grossman \&Helpman (1990) used endogenous growth models of trade which demonstrate the importance of technological progress and knowledge accumulation. The model generates an endogenous rate of long-run growth that relates business and development by means of diffusing technology and knowledge.

Another important consideration is trade openness. Yanikkaya (2002) revealed that there is a positive and significant association between trade openness and growth. As a country opens 
up its economy (imports plus exports as a ratio of GDP) and participates more in international business, it becomes integrated into the world economy and can enjoy the static and dynamic benefits accumulating from international business. According to Yanikkaya (2002), the most basic measure of openness are the simple trade shares, which are exports plus imports divided by GDP, and studies have found a positive and strong relationship with development.

\section{THEORETICAL FRAMEWORK}

\subsection{Comparative Advantage Theory}

David Ricardo propounded this theory. The theory assumed the existence of two countries, two commodities and one factors of production. In his theory, a country exports the commodity that has lower comparative advantage and import commodity whose comparative cost is higher. The theory also assumed that the level of technology is fixed for both nations and that trade is balanced and rolls out the flow of money between nations. However, the theory is based on the labor theory of values, which states that the price of the values of a commodity is equal to the labor time going into the production process. Labor is used in a fixed proportion in the production of all commodities (Usman, 2011).

\subsection{Hecksher - Ohlin Trade Theory}

Two Swedish economists, Eli Hecksher and Bertil Ohlin, promulgate this theory. The theory explains two issues in the theory of comparative advantage. First, what the factors that determine comparative advantage of countries are, and second, what the effects of trade on the factor of income in the trading countries are. On the assumption of equal or similar technology and tastes, Hecksher - Ohlin theory focuses on differences in relative factors of endowments and the factors of prices between nations as the major determinants of trade. The model identified difference in pre-trade product prices between nations as the basis for trade (Aremu \& Adeyemi, 2011).

The theory assumed two countries, two commodities and two factors. There is a perfect competition in both factors and the product market. It assumed that the factor inputs; labour and capital in these two countries, are homogeneous. Production function also exhibits a constant return to scale. The production possibility curve is concave to the origin. The model suggests that the less develop countries that are labor-abundant should specialize in the production of a primary product, especially an agricultural product because the labor requirement of agricultural is high except in the mechanized form of farming. On the other hand, the less developed countries should import capital-intensive products, mostly the manufactured goods from developed countries that are capital intensive (Weisbrot\&Baker, 2002).

\section{REVIEW OF EMPIRICAL LITERATURE}

Sun \& Heshmati (2010) examine the effects of international trade on China's SMEs growth. Applying econometric and non-parametric techniques on six - year data of 31 provinces in China from 2002 to 2007, their finding reveals that an increase participation in international trade 
helps stimulate rapid SMEs growth in China. Thus, the international trade volume and China's trade structure on technological exports positively affect China's regional productions.

Li, Chen \& San (2010) conducted a research on the relationship between foreign trade and the SMEs growth of East China for the period of 1981-2008. Adopting the unit root test, co-integration analysis and error correction model, they found out that foreign trade is the long-term and short-term reason of SMEs growth, but no evidence proved that there exists long-term stationary causality between the import trade and SMEs.

Mustafa (2011) analyzed the relationship between the foreign trade and SMEs growth in Turkey, using Vector Auto Regression model (VAR) and Vector Error Correction Model (VECM), and employed quarterly data of GDP, export and import for 1987 through 2007. He found out that in the short run, SMEs growth did not significantly depend on the export growth.

Rahmaddi \&Ichihashi (2011) investigated the relationship between exports and SMEs growth in Indonesia during the period of 1971-2008, using a VAR model. Based on the analysis conducted in a VECM framework, the authors revealed that exports and economic growth exhibit a bi-directional causal structure, and concluded that both exports and SMEs growth are significant to the economy of Indonesia. Sarbapriya (2011) examined the relationship between the foreign trade and SMEs growth in India, using annual data over the period of 1972-2011. The co integration and Granger causality tests confirmed that SMEs growth and foreign trade are co integrated, implying the existence of a long-run equilibrium relationship between the two, and the presence of bi-directional causality which runs from SMEs growth to foreign trade and vice versa.

Javed, Qaiser, Mushtaq, Saif-ullaha \& Iqbal (2012) examined the impact of total exports to SMEs ratio, import to GDP, terms of trade, trade openness, investment to GDP ratio and inflation on the Pakistani economy using time-series data from the1973-2010. Employing the Chow test and Ordinary Least Square method, the estimated results revealed that all the explanatory variables have a positive and significant impact on Pakistan. The study further discovered that an increase in the import of raw materials boosted production, employment and output of Pakistan.

Omoke \& Ugwuanyi (2010) used Granger causality and co integration tests to investigate the relationship between export, domestic demand and SMEs in Nigeria. The results from Trace and Maximum Eigen Value test conducted showed that the variables do not have a long-run relationship, but the Pair-wise Granger Causality test showed that SMEs Granger causes both export and domestic demand, while a bilateral causality exists between export and domestic demand.

Ezike, Ikpesu, \& Amah (2012) investigate the macroeconomic impact of business on Nigerian growth. Using the Ordinary Least Square (OLS) regression technique and applying a combination of bivariate and multivariate models from the data covering the period 1970-2008 observed that the two predictors used in the study for trade, namely exports and foreign direct investment have a positive and significant impact on Nigeria’s SMEs growth during the period.

Omoju \& Adesanya, (2012) investigate trade and growth in developing country using Nigeria as a case study. They make use of secondary data from 1980-2010 and applying the Ordinary Least Square (OLS) regression method. They found out that the foreign trade, foreign direct investment, government expenditure and exchange rate have a significant positive impact on growth in developing countries. 
In the same vein, Eravwoke \& Oyivwi (2012) studies growth perspective via trade in Nigeria, using the Ordinary Least Square (OLS) method, Augmented Dickey Fuller (ADF) and the Johansen co-integration statistical approach on data covering the period of 1970-2009. They found out that the ADF reveals that the series are integrated of order one 1(1), but for a total trade the series became stationary after taking the second difference $1(2)$, and concludes that the variables are non-stationary. The Johansen co integration test shows that there exists one co-integration equation at $5 \%$ level of significance, which means that there is a long run relationship between the total trade, exchange rate, export and gross domestic product of Nigeria. The OLS result revealed that the total trade and export are not statistically significant in explaining growth in Nigeria, however the exchange rate is statistically significant in explaining growth in Nigeria.

Adelowokan \& Maku (2013) examined the effect of trade and financial investment openness on growth in Nigeria between 1960 and 2011. Estimates from the reported dynamic regression model indicated that trade openness and foreign investment exert a positive and negative effect on economic growth respectively. Also, the partial adjustment term, fiscal deficit, inflation and lending rate were found growth increasing. It was evidenced that a long-run relationship exists among trade openness, foreign investment, and economic growth in Nigeria.

Edoumiekumo \& Opukri (2013) examined the contributions of international trade (proxy with export and import values) to growth in Nigeria measured by real gross domestic product (RGDP). Time-series data obtained for a period of 27-year was analyzed using Augmented Dickey-Fuller (ADF) test, Ordinary Least Square (OLS) statistical technique, Johansen co-integration test and Granger Causality test. The results showed that a positive relationship exists between the variables and there is co-integration among the variables. The Granger Causality test showed a unidirectional relationship which show that the RGDP Granger cause export and import Granger cause RGDP and export.

Having reviewed various past researches on the subject matter, the following null hypotheses are formulated to guide this study:

H1: Trade openness does not significantly affect SMEs growth in Nigeria.

H2: Foreign Direct Investment (FDI) has no significant influence on SMEs growth in Nigeria.

H3: Exchange rate has no significant effect on SMEs growth in Nigeria.

H4: International business does not have an overall effect on SMEs growth in Nigeria.

\section{METHODOLOGY}

This research work adopts a longitudinal research design to compliment the research effort. This method of research design is embraced to describe the pattern of changes in the variables overtime, and help establish the direction and magnitude of causal relationships. A secondary data is used in this research work. The data were generated from the Nigerian Bureau of Statistics (NBS) and the Central Bank of Nigeria (CBN) annual report. The data generated in this study was analyzed using the OLS technique, which was employed to test the overall effect of the independent variable on the dependent variable. The data gathered are analyzed using E-views (v7). 
A multiple regression model is used to explain the relationship between the dependent variable (SMEs growth) and the independent variable (international business). The mathematical equation below therefore shows the effect of the independent variable on the dependent variable in a linear form as follows:

SMEsGRWTH $=f(E X C R A T, F D I$, OPNSS)

Where:

SMEs GRWTH = SMEs Growth

$\operatorname{EXCR} A T=$ Exchange rate

$F D I=$ Foreign Direct Investment

OPNSS $=$ Trade Openness

This can be specifically expressed in an explicit econometric form as:

SMEsGRWTH $=\alpha_{0}+\alpha_{1}$ EXCRAT $+\alpha_{2}$ FDI $+\alpha_{3}$ OPNSS $+U t$

Where

$U=$ stochastic or random error term (with usual properties of zero mean and non-serial correlation).

$\alpha_{1}-\alpha_{3}=$ Co-efficient of associated variables,

$\alpha_{0}=$ Constant Intercept.

A log- linear form is more likely to find evidence of a deterrent effect than a linear form; the equation is therefore log-linearized as follows:

LOGSMEsGRWTH $=\alpha_{0}+\alpha_{1}$ LOGEXCRAT $+\alpha_{2}$ LOGFDI $+\alpha_{3}$ LOGOPNSS $+U t$

The 'a priori' expectation is the expected relationship each exogenous variable is predicted to have with the endogenous variable. For the study, $\alpha_{1}, \alpha_{2}, \alpha_{3}>0$, this implies that all the exogenous variables are expected to have a positive relationship with the endogenous variable.

\section{RESULTS}

\section{Hypotheses testing}

\section{H1: Trade openness does not significantly affect SMEs growth in Nigeria.}

- Dependent variable: SMEs Growth

- Method: Least Squares

- Sample: 2005-2014

- Included observations: 10 
Tab. 1 - Ordinary Least Square

\begin{tabular}{|l|r|r|r|l|}
\hline Variable & Coefficient & Std. Error & t-Statistics & Prob. \\
\hline C & -2.851882 & 2.607954 & -1.093533 & 0.3060 \\
\hline Trade openness & 1.306010 & 0.673451 & 1.939281 & 0.0884 \\
\hline R-squared & 0.319775 & & & \\
\hline Adjusted R-squared & 0.234747 & & & \\
\hline S.E. of regression & 0.259003 & & & \\
\hline F-statistic & 3.760812 & & & \\
\hline Prob(F-statistic) & 0.088444 & & & \\
\hline Durbin-Watson stat. & 1.744227 & & & \\
\hline
\end{tabular}

The individual effect of trade openness on SMEs growth was analyzed using ordinary least squares. The total variance of the variables explained by the analysis in the R Square was $31.9 \%$, $\mathrm{F}=3.760812, \mathrm{p}>.005$, which is insignificant. It can therefore be said that trade openness has no significant effect on SMEs growth in Nigeria, and the level at which it affects SMEs growth is relatively low. Thus, the null hypothesis, which says that trade openness, does not significantly affect SMEs growth in Nigeria should be accepted while rejecting the alternate hypothesis. More so, the Durbin-Watson value is 1.553744 , indicating no autocorrelation in the data, hence giving a reliable and non-spurious result.

H2: Foreign Direct Investment (FDI) has no significant influence on SMEs growth in Nigeria.

- Dependent variable: SMEs Growth

- Method: Least Squares

- Sample: 2005-2014

- Included observations: 10

Tab. 2 - Ordinary Least Square

\begin{tabular}{|l|r|r|r|r|}
\hline Variable & \multicolumn{1}{|l|}{ Coefficient } & Std. Error & \multicolumn{1}{l|}{ t-Statistics } & \multicolumn{1}{l|}{ Prob. } \\
\hline C & 8.723240 & 19.93859 & 0.437505 & 0.6733 \\
\hline FDI & -0.289299 & 0.883554 & -0.327426 & 0.7517 \\
\hline R-squared & 0.013224 & & & \\
\hline Adjusted R-squared & -0.110123 & & & \\
\hline S.E. of regression & 0.640024 & & & \\
\hline F-statistic & 0.107208 & & & \\
\hline Prob(F-statistic) & 0.751749 & & & \\
\hline Durbin-Watson stat. & 0.863249 & & & \\
\hline
\end{tabular}

The individual effect of FDI on SMEs growth was analyzed using ordinary least squares. The total variance of the variables explained by the analysis in the $\mathrm{R}$ Square was $1.3 \%, \mathrm{~F}=0.107208$, 
$\mathrm{p}>.005$, which is not significant. It can therefore be said that FDI has no significant effect on SMEs growth in Nigeria, and the level at which it affects SMEs growth is relatively low. Thus, the null hypothesis which says that Foreign Direct Investment (FDI) has no significant influence on SMEs growth in Nigeria should be accepted while rejecting the alternate hypothesis.

\section{H3: Exchange rate has no significant effect on SMEs growth in Nigeria.}

- Dependent variable: SMEs Growth

- Method: Least Squares

- Sample: 2005-2014

- Included observations: 10

Tab. 3 - Ordinary Least Square

\begin{tabular}{|l|r|r|r|r|}
\hline Variable & Coefficient & Std. Error & t-Statistics & \multicolumn{1}{l|}{ Prob. } \\
\hline C & 22.69761 & 6.531144 & 3.475288 & 0.0084 \\
\hline EXCHANGE RATE & -4.134642 & 1.316821 & -3.139865 & 0.0138 \\
\hline R-squared & 0.552040 & & & \\
\hline Adjusted R-squared & 0.496045 & & & \\
\hline S.E. of regression & 0.431228 & & & \\
\hline F-statistic & 9.858754 & & & \\
\hline Prob(F-statistic) & 0.013808 & & & \\
\hline Durbin-Watson stat. & 2.117431 & & & \\
\hline
\end{tabular}

The individual effect of exchange rate on SMEs growth was analyzed using ordinary least square analysis. The total variance of the variables explained by the model as a whole in the $\mathrm{R}$ Square was $55.2 \%, F=9.858754, \mathrm{p}<.005$. It can be explained that the exchange rate affects SMEs growth up to $55.2 \%$. It can therefore be said that the exchange rate has a significant effect on SMEs growth in Nigeria, and the level at which the exchange rate affects SMEs growth is relatively high. It can further be revealed that the coefficient of exchange rate is -4.134642 , which implies that the exchange rate reduces, SMEs growth increases, which follows the normal theory and the rule of theory. Thus, the null hypothesis, which says that the exchange rate has no significant effect on SMEs growth should be rejected while accepting the alternate hypothesis.

H4: International business does not have an overall effect on SMEs growth in Nigeria.

- Dependent variable: SMEs Growth

- Method: Least Squares

- Sample: 2005-2014

- Included observations: 10 
Tab. 4 - Ordinary Least Square

\begin{tabular}{|l|r|r|r|l|}
\hline Variable & Coefficient & Std. Error & t-Statistics & Prob. \\
\hline C & 22.69761 & 6.531144 & 3.475288 & 0.0084 \\
\hline FDI & -0.361480 & 1.032579 & -0.350075 & 0.7382 \\
\hline TRADE OPENESS & 0.231058 & 1.579583 & 0.146278 & 0.8885 \\
\hline EXCHANGE RATE & -3.671381 & 3.429594 & -1.070500 & 0.3256 \\
\hline R-squared & 0.563285 & & & \\
\hline Adjusted R-squared & 0.344928 & & & \\
\hline S.E. of regression & 0.491649 & & & \\
\hline F-statistic & 2.579646 & & & \\
\hline Prob(F-statistic) & 0.149126 & & & \\
\hline Durbin-Watson stat. & 2.126119 & & & \\
\hline
\end{tabular}

The overall effect of international business on SMEs growth was analyzed using ordinary least square method. The total variance of the variables explained by the analysis as a whole in the $\mathrm{R}$ Square was $56.3 \%, \mathrm{~F}=2.579646, \mathrm{p}>.005$, which is not significant. It can be explained that international business does not have a significant effect on SMEs growth. It can therefore be said that international business has no overall significant effect on SMEs growth in Nigeria. Thus, the null hypothesis, which says that international business has no overall significant effect on SMEs growth, should be accepted.

\section{CONCLUSION AND RECOMMENDATIONS}

The findings of the analysis revealed that international business does not have a significant effect on SMEs growth. It can therefore be said that international business has no overall significant effect on SMEs growth in Nigeria. Thus, the null hypothesis, which says that international business has no overall significant effect on SMEs growth, should be accepted. The finding further revealed that trade openness has no significant effect on SMEs growth in Nigeria, and the level at which it affects SMEs growth is relatively low. Thus, the null hypothesis, which says that trade openness, does not significantly affect SMEs growth in Nigeria should be accepted while rejecting the alternate hypothesis.

More so, the finding revealed that FDI has no significant effect on SMEs growth in Nigeria, and the level at which it affects SMEs growth is relatively low. Thus, the null hypothesis, which says that Foreign Direct Investment (FDI) has no significant influence on SMEs growth in Nigeria should be accepted while rejecting the alternate hypothesis. Finally, it was discovered that the exchange rate has a significant effect on SMEs growth in Nigeria, and the level at which the exchange rate affects SMEs growth is relatively high. It can further be revealed that the coefficient of exchange rate -4.134642 is negative which implies that as the exchange rate reduces, SMEs growth increases, which follows the normal theory and follows the rule of theory.

The study examines the individual and composite effect of international business on SMEs growth. The study does not record a significant effect of each of the international business vari- 
ables on SMEs growth. This implies that not all the variables significantly affect SMEs growth in Nigeria. To this effect, more attention should be paid to the exchange rate because it significantly determines the level of SMEs growth in Nigeria.

Based on the findings, it is recommended that the government should formulate policies, which will encourage the reduction of exchange rate in the country in order to improve business activities across the country, and improve the growth of SMEs across the country, as well as encouraging entrepreneurship spirit in the country.

\section{References}

1. Adelowokan, O. A., \& Maku, A. O. (2013). Trade openness, foreign investment and economic growth in Nigeria: A long-run analysis. European Journal of Globalization and Development Research, 7(1), 446-458.

2. Agbeyebge, T. D., Stotsky, J., \& Wolde, A. (2006). Trade liberalization, exchange rate changes, and tax revenue in Sub-Saharan African. Journal of Asian Economics, 17(2), 261-284.

3. Aregbeyen, J. B. O. (1999). Constraints of small and medium-scale enterprises in sourcing funds from the Nigerian stock market. Nigerian Institute of Social and Economic Research.

4. Aremu, M. A. (2010). Small and medium scale enterprises capacity building in Nigeria. A paper presented at the International Conference on management and Enterprise Development on "Intellectual and New Strategies for Sustainability Development of the Third World" Held at Conference Centre, University of Ibadan, Nigeria Oct.5th - 8th

5. Aremu, M. A., \& Adeyemi, S. L. (2011).Small and medium scale enterprises as a survival strategy for employment generation in Nigeria .Journal of Sustainable Development, 4(1), 56-72.

6. Ariyo, D. (2004). Small firms are the backbone of the Nigerian economy. African Economic Analysis, Africa Business Information Services, Bridgnorth.

7. Australian Bureau of Statistics (2001). Small business in Australian. Catalogue No. 1321,Cammberra.

8. Chen, H. (2009). A literature review on the relationship between foreign trade and economic growth. International Journal of Economics and Finance, 1(1), 127-131.

9. Edoumiekumo, S. G., \& Opukri, C. O. (2013). Economic growth factor in Nigeria: The role of global trade. American Journal of Humanities and Social Sciences, 1(2), 51-55.

10. Edwards, S. (1998). Openness, productivity and growth: What do really know? Economic Journal, 108(1), 383-398.

11. Eravwoke, K. E., \& Oyovwi, D. O. (2012). Growth perspective via trade in Nigeria: A co integration approach. African Research Review: An International Multidisciplinary Journal,6(1), $18-26$.

12. Ezeh, J. A. (1999). Fundamentals of small business management. Enugu: Glanic Books.

13. Ezike, J. E., Ikpesu, F., and Amah, P. (2012). Macroeconomic impact of trade on Nigerian growth: An empirical evaluation. Research Journal of Business Management and Accounting, 1(4), $79-83$. 
14. Gianni De, N., Honohan, P., and Ize, A. (2003).Dollarization of the banking system: good or bad? IMF working paper.

15. Grosman, G.,\& Helpman, H.(1990).Comparative advantage and long-run growth. American Economic Review, 80(4), 796-815.

16. Gunu, U. (2004). Small scale enterprises in Nigeria: their start-up, characteristics, sources of finance and importance. Ilorin Journal of Business, 15(2), 63-75.

17. Javed, Z. H., Qaiser, I., Mushtaq, A., Saif-ullaha, and Iqbal, A. (2012). Effects of international trade on economic growth: The case study of Pakistan. International Journal of Academic Research in Progressive Education and Development, 1(2), 103-113.

18. Jhingan, M. L. (2006). Economic Development and Planning. 35th Edition, Vrinda Publications (P) LTD.

19. Li, Y., Chen, Z., \& San, C. (2010).Research on the relationship between foreign trade and the GDP growth of East China- empirical analysis based on causality. Modern Economy, 1(1), $118-124$.

20. Mustafa, K. (2011). An analysis of the relationship between foreign trade and economic growth in Turkey over the period (1980-2009). Lund University School of Economics and Management, Turkey. Unpublished Ph.D. Thesis.

21. Obadan, M. I. (2006). Economic globalization, markets and national development: how sensibly do the poor countries (Nigeria included) stand? Inaugural Lecture Series 98, University of Benin, Benin City.

22. Obamuyi, T. M. (2007). An exploratory study of loan delinquency among small and medium enterprise (SMEs) in Ondo State of Nigeria. Labour andManagement Development Journal, 8(1) 1-10.

23. Ojeka, A., \& Mukoro, O. O. (2011). International financial reporting standard (IFRS) and SMEs in Nigeria: perceptions of academic. International Journal of Research in commerce and Management, 2(1), 13-20.

24. Omoju, O., \&Adesanya, O. (2012). Does trade promote growth in developing countries? Empirical evidence from Nigeria. International Journal of Development and Sustainability, 1(3), 56-65.

25. Omoke, P. C., \&Ugwuanyi, C. U. (2010). Export, domestic demand and economic growth in Nigeria: Granger causality analysis. European Journal of Social Sciences, 13(2), 531-541.

26. Onugu, B. A. N. (2005). Small and medium enterprises (SMEs) in Nigeria: problems and prospects. Ph.D. thesis, St. Clements University, Australia.

27. Paul, P. (2009). Direction of standards for SMES: IFRS for SMEs. International Accounting Standards Board Review, 2(1), 3-5.

28. Rahmaddi, R.,\& Ichihashi, M. (2011).Exports and economic growth in Indonesia. A causality approach based on multi-variate correction model. Journal of International Development and Cooperation, 17(2), 53-73.

29. Rodriquez.,\& Oderick, D. (2000). Trade policy and economic growth: a skeptic's guide to the cross-national evidence. National Bureau of Economic Research Working Paper No. 7081, Washington. 
30. Sarbapriya, R. (2011). Explaining co-integration and causality between foreign trade and economic growth: Econometric evidence from India. International Journal of Contemporary Business Studies, 2(10), 126-142.

31. Shafaeddin, S. M. (2005). Trade liberalization and economic reform in developing countries, structural change or de-industrialization? Discussion Paper, No. 179, United Nations Conference on Trade and Development, Geneva.

32. Small \& Medium Industries Equity Investment Scheme (SMIEIS) (2006). A paper presented at The national summit on SMIEIS. Organized by the Bankers' Committee and Lagos Chambers of Commerce and Industry (LCCI), Lagos.

33. SMEDAN (2005).Small and medium enterprises performance in Nigeria. A report presented at African entrepreneurship seminar organized in collaboration with the Scientific Committee on Entrepreneurship of the University of Essex. United Kingdom on the 5 th of June.

34. Sun, P., \& Heshmati, A. (2010).International trade and its effects on economic growth in China. Discussion Paper No. 5151 August.

35. Terungwa, A. (2011). Risk management and insurance of small and medium scale enterprises (SMEs) in Nigeria. International Journal of Finance and Accounting, 1(1), 8-17.

36. Thirlwall, A. P. (1997). Reflections on the concept of balance of payments constrained growth, Journal of post Keynesian Economics, 19(3), 337-385.

37. Weisbrot, M., \& Baker, D. (2002).The relative impact of trade liberalization on developing countries. Centre For Economic and Policy Research, Washington, D.C.

38. Yanikkaya, H. (2003). Trade openness and economic growth: A cross-country empirical investigation. Journal of Development Economics, 72(1), 57- 89.

\section{Contact Information}

Dr. Moruff Sanjo Oladimeji (Ph.D.)

Department of Business Administration,

Faculty of Social \& Management Sciences,

Olabisi Onabanjo University, Ago - Iwoye,

Ogun State, Nigeria

Email:sanjolanre4life@yahoo.com

Ibrabim, Olaniyi Mubammed

Department of Marketing

Moshood Abiola Polytechnic,

Abeokuta, Ogun State 